\title{
Performance Management System of a Security Agency in the Philippines
}

\author{
Jay Amistoso ${ }^{1}$, Jonathan O. Etcuban ${ }^{2}$, Eddie Llamedo ${ }^{3}$, Judy Ann Gimena ${ }^{4}$, \\ Dennis Capuyan $^{5}$ and Bernabe Lumantas ${ }^{6}$ \\ ${ }^{1}$ Student, ${ }^{3 \& 5}$ Faculty, University of Cebu, Cebu City, Philippines \\ ${ }^{2,4 \& 6}$ Faculty, Cebu Technological University, Cebu City, Philippines \\ E-Mail: amistosojayc@gmail.com, joetcuban@gmail.com, eddie_llamedo@yahoo.com.ph
}

\begin{abstract}
The human asset is for the most part acclaimed as the most significant asset. It is through the human asset that an organization can make the most advising commitment to its aggressive edge and eventually, its main concern gainfulness or acknowledgment of its destinations. The study determined the performance management practices of a Security Agency in Cebu, Philippines. The study used a descriptive correlational design. The respondents were the 131 respondents consisted of security guards, security officers, head guards, and shifts-incharge. They were advised to answer the researcher-made questionnaire. The accumulated information was investigated utilizing recurrence, straightforward rate, weighted mean, and Chi-square trial of autonomy. The discoveries uncovered that most of the respondents assessed that performance management was highly practiced as to commitment and target setting, performance appraisal, monitoring and evaluation, and developmental intervention. It was concluded that the level of best practices and administration of performance management practices is highly practiced as managers continuously conduct monitoring on their plans and actions in order to maintain effectiveness and efficiency in carrying out the functions of the management. The researchers recommend the adoption and implementation of the proposed performance management system manual.
\end{abstract}

Keywords: Social Science, Performance, Descriptive Method, Philippines

\section{INTRODUCTION}

In the entire world, security plays a significant role in the preservation of world peace; a world that is safe and secured is a world that is progressive and developed (Peckley \& Fontanos, 2012). National interest is attaining through cooperation and coordination of all the nations. This will serve in promoting the economic development of the international and local economy. In the Philippines, wellbeing, security just as harmony and request in both government and private foundations depends on such a significant amount in utilizing security officers, usually assigned as security watches. The essential distraction of the said workforce whether be it private security, organization or government security monitors, is make sure whoever is inside the structure, foundation or office under their supervision is sheltered from any mischief, savagery or something else, which might be malignantly arranged by another substance for monetary profit, vengeance or terrorist motives (Bautista, 2008).

Primarily the job of the security personnel is to protect its clients against possible death, injuries, losses, damages and or destruction of properties. In business parlance, security is like a commodity. It is one of the interior elements in business if they yearn profitability and continuity in their financial service (Peckley \& Fontanos, 2012). Security guards are the key security personnel in the whole business. They should have enough learning of the fundamental capacities and obligations in securing life and property of the customers.

Employing security guards are widely accepted today of finding the solutions for a problem in securing life and property. It was observed that most of the company in Cebu City uses security guard. Unfortunately, some of the security guards need to improve their level of capability. Security guards are the key security personnel in the entire business. They have enough knowledge of the essential functions and responsibilities in securing life and property. In this connection, the capability of the security guards made the security client and security agency manifest the kind of security personnel they had acquired.

Organizations are run and guided by individuals. It is through individuals that goals are set and objectives are realized. The execution of an association is subject to the oumarytline of the execution of its individuals. The achievement of an association will along these lines rely upon its capacity to quantify precisely the execution of its individuals and use it dispassionately to streamline them as an indispensable asset. In the field of security management, performance management practice plays a massive role in ensuring the success of the security personnel not only professionally but also contributes to their overall well-being. Frequent practice of sound performance management creates a culture of excellence for the security agency and sets it apart from its competitors. This guarantees a progressive mindset of individuals in the workplace. It is the reality of the security agency to recognize security personnel who do better than their peers.

Every security personnel can make a difference to the overall success both in the security agency and the client. The fundamental dilemma that is faced today both by individuals and management is how to fairly and objectively manage their security personnel's performance to maximize both personal contribution and overall profitability. It was observed that, there is room for improvement in providing opportunities to the security personnel to accomplish their 
targets, receiving assessment from client's representatives for detachment commander's performance, recommending introduction or abolition of policies to the client as applicable based on the observations of its security personnel and giving recommendation to client for disposition of its security personnel. Thus, this leads to high employee turnover thereby affecting employee commitment in the security agency. Hence, establishing effective performance management practices and structured methods of identifying poor performance and improving performance is the most effective management approach.

As a human resource officer for about three years in service in the field of security aimed at aligning security personnel's work efforts with the objectives both security agency and client, manage these efforts on a daily basis, evaluate and monitor security personnel performance, reward security personnel accordingly, and stimulate individual development to enhance employee contribution to the security agency's success. Therefore, it is essential that this research is conducted to understand security personnel's experiences and perceptions of performance management practices so that a completed and comprehensive performance system could be built up. Furthermore, the researcher realized that the real purpose of performance management practice is to measure the company's progress in the process of reaching its goals. Thus, the researcher pursued this study.

\section{OBJECTIVES OF THE STUDY}

This study determined the performance management practices of a Security Agency in Cebu, Philippines2018. The findings of the study served as the basis for the proposed performance management system manual. It answered the: 1.) Profile of the respondents; 2) Performance management practices of a security agency in terms of Commitment and Target Setting, Performance Appraisal, Monitoring and Evaluation, and Developmental intervention; and 3) Significant relationship between the respondents' profile and their performance management practices.

\section{METHODOLOGY}

This study used the descriptive-correlational method using self-made survey questionnaires. This study was conducted in Cebu, Philippines where the security agency is located. The Security Agency is serving different companies in the provinces of $\mathrm{Cebu}$ and its neighbouring provinces. The respondents were the 131 security personnel consisted of 113 security guards, four security officers, seven head guards, and seven shifts-in-charge of the security agency. This study used a researcher-made questionnaire as the primary device in gathering data and information. The questionnaire consisted of two parts: the first part pertains to the respondent's profile that includes age, gender, civil status, highest educational attainment, and length of service as security personnel. The second part is on the performance management practices of the security agency, which includes commitment and target setting, performance appraisal, monitoring and evaluation, and developmental intervention. The respondents answered the questions using the following legend: 4 points for highly practiced, 3 points for moderately practiced, 2 points for less practiced and 1 point for not practicing. Directions were provided by the researchers to help guide the respondents on how to go about each of the items. Further instructions were given orally to ensure clarity of instruction. The data obtained were tallied, tabulated, analyzed, and interpreted using frequency, simple percentage, weighted mean, and Chisquare test of independence.

\section{RESULTS AND DISCUSSION}

A. Profile of the Respondents: The profile of the respondents includes age, gender, civil status, highest educational attainment, and length of service as security personnel.

TABLE I PROFILE OF THE RESPONDENTS ( $\mathrm{N}=131)$

\begin{tabular}{|c|c|c|}
\hline & Frequency & Percentage \\
\hline \multicolumn{3}{|c|}{ A. Age (in years) } \\
\hline $20-25$ & 27 & 20.61 \\
\hline $26-31$ & 29 & 22.14 \\
\hline $32-47$ & 67 & 51.15 \\
\hline $48-56$ & 8 & 6.11 \\
\hline $\begin{array}{l}\text { Mean : } 34.084 \\
\text { St Dev : } 8.383\end{array}$ & & \\
\hline \multicolumn{3}{|c|}{ B. Gender } \\
\hline Female & 16 & 12.21 \\
\hline Male & 115 & 87.79 \\
\hline \multicolumn{3}{|c|}{ C. Civil Status } \\
\hline Married & 59 & 45.04 \\
\hline Single & 70 & 53.44 \\
\hline Widow & 2 & 1.53 \\
\hline \multicolumn{3}{|c|}{ D. Highest Educational Attainment } \\
\hline College Graduate & 18 & 13.74 \\
\hline College Level & 27 & 20.61 \\
\hline High School Graduate & 86 & 65.65 \\
\hline \multicolumn{3}{|c|}{$\begin{array}{r}\text { E. Length of Service } \\
\end{array}$} \\
\hline $1-3$ months & 4 & 3.05 \\
\hline $4-6$ months & 6 & 4.58 \\
\hline 7 months -1 year & 11 & 8.40 \\
\hline $1-3$ years & 31 & 23.66 \\
\hline $4-5$ years & 21 & 16.03 \\
\hline $6-10$ years & 37 & 28.24 \\
\hline $11-15$ years & 18 & 13.74 \\
\hline $16-20$ years & 1 & 0.76 \\
\hline More than 20 years & 2 & 1.53 \\
\hline
\end{tabular}


As shown in the table I, the majority of the respondents belonged to the age group of 32-47 years old. Under RA 5487 , the age requirement for a security guard is from 21-50 years old. Under the law, this is the legal standard in order to procure a license to exercise security profession. The client prefers this category because they are neither too inexperienced nor physically disadvantaged.

Majority of the respondents were male. In most cases, male security personnel are most likely to be selected by the clients because they are generally considered to be the stronger sex. Males dominate the field of security because of their advantage in terms of their built, strengths, capacity, physical capabilities and competencies compared to women especially if assigned in a sensitive area. Female security guard/lady guard is an option of the client if the functions/duties and responsibilities require less the application of the strengths, and more often lady guards are assigned of written works such as records of incoming/upcoming commodities and stocks, records of employees time in and out and receives calls for appointment.

In terms of civil status, a large number of them were single. $45.04 \%$ of the respondents were legally married, and $1.53 \%$ is widowed. Based on the survey, it reveals that some security personnel have live-in partners but not legally married. The only security personnel were the most willing to be posted immediately on short notice. They have a motto the "strike anywhere." They have fewer things to consider when accepting a post compared to their married peers. Factors such as change of residents and distance to loved ones play a significant part in their decision-making process. If offered a post in a different city or even in a different province, married security personnel usually consult their wives first.

Most of the respondents are high school graduates. Only $20.61 \%$ of the respondents are college level, and $13.74 \%$ were college graduates. Under RA 5487, the qualifications for educational attainment in hiring a security guard are only high school graduate. However, based on the data gathered, there were even security guards who are college level and college graduate. It does not limit the requirements of college level or college graduate because there were even college graduates who hold the position of a security guard depending on the license they have.

Lastly, as to their length of service, the majority of the security personnel respondents had been connected with the security agency for six to ten years in security work because the earliest age that qualifies for a license is twenty-one years old. A more substantial part of the respondents had a place with the age gathering of $32-47$ years of age. It is normal that the majority of the respondents have been in the business for some time and sixteen to twenty years among the last time that was experienced by the security workforce respondents.

\section{B. Performance Management Practices}

Table Ii Perceived Performance Management Practices As To Commitment And Target Setting

\begin{tabular}{|c|l|c|c|}
\hline & \multicolumn{1}{|c|}{ Indicators } & Mean & Interpretation \\
\hline 1. & $\begin{array}{l}\text { The management thru its detachment commanders has defined targets for each security } \\
\text { personnel to meet the standard of the security agency. }\end{array}$ & 3.66 & Highly Practiced \\
\hline 2. & $\begin{array}{l}\text { The management thru its detachment commanders has defined targets for each security } \\
\text { personnel to meet the standard of the client. }\end{array}$ & 3.54 & Highly Practiced \\
\hline 3. & $\begin{array}{l}\text { The management ensures that the targets are SMART (Specific, Measurable, } \\
\text { Attainable, Realistic and Time-bound). }\end{array}$ & 3.53 & Highly Practiced \\
\hline 4. & The management provides opportunities for the detachment to accomplish its targets. & 3.27 & Highly Practiced \\
\hline 5. & The management sets similar goals across all detachment. & 3.30 & Highly Practiced \\
\hline 6. & $\begin{array}{l}\text { The management supports the detachment commanders in their initiatives to achieve } \\
\text { the set goals. }\end{array}$ & 3.34 & Highly Practiced \\
\hline 7. & The management incorporates the security agency's goals with that of the client. & 3.49 & Highly Practiced \\
\hline & Aggregate Mean & 3.45 & Highly Practiced \\
\hline
\end{tabular}

The table II presents the data on the performance management practices as to commitment and target setting with an aggregate mean of 3.45 or highly practiced.

The study reveals that management through its detachment commanders has highly practiced in defined targets for each security personnel to meet the standard of the security agency, based on the weighted mean of 3.66. These data imply that the security agency management together with the detachment commanders ensure that their security personnel activities and outputs are congruent with the security agency's goals and targets. Committed security personnel will have the impact of focusing on setting goals in the security agency, at both departmental and individual goals. This is accomplished through effectively recognizing security personnel's training and development needs and giving helpful criticism to the security personnel on their performance. This enables security personnel to enhance and build up their skill sets within their role.

On the other hand, the management highly practiced in providing the opportunities for the detachment to accomplish its targets under commitment and target setting as indicated by the weighted mean of 3.27 . This is the 
lowest mean. This result implies that there is a room for improvement in discussing the security agency's goals to accomplish the detachment commander's targets for the growth and improvement of the security agency. Commitment is fundamental to a worker's responsibility and an organization's capacity to hold a representative. An organization can encourage representative responsibility by helping representatives to set business related objectives that give job clearness and heading. A worker is bound to remain with an organization on the off chance that he comprehends the organization's desires for him and the commitment that his objectives make to the organization's necessary arrangement. In a domain where labourers are locked in, workers endeavour to accomplish their goals. These representatives are focused on the organization, anticipating an uplifting mentality about their business to their colleagues and their clients. The setting, progressing in the direction of and accomplishing objectives add to representative responsibility by making a worker feel like an essential piece of the association. The more explicit the association between worker goals and friends destinations, the almost certain the representative is to see how her work influences the organization's primary concern. Numerous associations pursue the "Savvy" objective setting model, in which chief's work with representatives to set objectives that are explicit, quantifiable, achievable, sensible and timebound. Savvy objectives cultivate representative responsibility by giving a feeling of achievement when the worker accomplishes the objective.

Counting representatives in the objective setting process encourage labourers to comprehend their objectives and to make inquiries about them. A representative who takes an interest in the objective setting process is bound to reach outside his usual range of familiarity and take on testing objectives.

Representatives must remember the organization's needs when defining objectives. A long-lasting representative with great institutional learning of an association should make it an objective to pass on his mastery to less-tenured specialists (Lindblad, 2007).

Table Iit Perceived Performance Management Practices As To Performance ApPraisal

\begin{tabular}{|c|l|c|c|}
\hline & \multicolumn{1}{|c|}{ Indicators } & Mean & Interpretation \\
\hline 1. & $\begin{array}{l}\text { The management conducts regular troop formation and inspection to check } \\
\text { compliance with the security agency's prescribed grooming and appearance. }\end{array}$ & 3.41 & Highly Practiced \\
\hline 2. & $\begin{array}{l}\text { The management conducts a post-to-post inspection to evaluate compliance with } \\
\text { security agency and client instruction. }\end{array}$ & 3.32 & Highly Practiced \\
\hline 3. & $\begin{array}{l}\text { The management coordinates with the client to ensure satisfaction with the security } \\
\text { personnel's performance. }\end{array}$ & 3.38 & Highly Practiced \\
\hline 4. & $\begin{array}{l}\text { The management gathers feedback from detachment commanders with their } \\
\text { respective security personnel's performance. }\end{array}$ & 3.29 & Highly Practiced \\
\hline 5. & $\begin{array}{l}\text { The management receives an assessment from the client's representatives for the } \\
\text { detachment commander's performance. }\end{array}$ & 3.25 & Highly Practiced \\
\hline 6. & $\begin{array}{l}\text { The management evaluates security personnel's effectiveness in implementing client } \\
\text { and security agency policies. }\end{array}$ & 3.55 & Highly Practiced \\
\hline 7. & $\begin{array}{l}\text { The management organizes a joint assessment of its security personnel together with } \\
\text { its client. }\end{array}$ & 3.45 & Highly Practiced \\
\hline & Aggregate Mean & 3.38 & Highly Practiced \\
\hline
\end{tabular}

The table III presents the result of their performance management practices as to performance appraisal. The aggregate mean obtained is 3.38 or highly practiced. As indicated in the table, the security personnel rated the management based on their performance management practices as highly practiced in terms of performance appraisal. The results revealed in the context of the management evaluation of security personnel's effectiveness in implementing client and security agency policies were highly practiced based on the weighted mean of 3.55. This indicates that a security guard is often the first person a visitor encounters when entering a facility or premises of the organization. Consequently, it is imperative that protects are very much prepared and inspired to play out their obligations to the best of their capacities. Their effectiveness in implementing client policy is the most common basis of good performance appraisal. Client representation together with detachment commanders evaluates the security personnel regularly. Troop inspection is conducted daily through guard mounting before the start of the shift.

On the other hand, the weighted mean of 3.25 indicated that management receives an assessment from the client's representatives for the detachment commander's performance is highly practiced. This is with the lowest mean. This implies that there is an opportunity to get better in the assessment process in terms of performance appraisal that acts as motivation for an employee to improve his productivity. Performance Appraisal is a procedure that includes deciding and imparting to workers how work is being performed and set up an arrangement for development. Some of the more common uses of performance appraisals are to make decisions related to merit pay increases of promotion, layoffs, and firings (Rue et al., 2013).

Table IV presents the responses to performance management practices as to monitoring and evaluation. 
Table Iv Perceived Performance Management Practices As To Monitoring And Evaluation

\begin{tabular}{|c|l|c|c|}
\hline \multicolumn{1}{|c|}{ Indicators } & Mean & Interpretation \\
\hline 1. & $\begin{array}{l}\text { The management coordinates with the client to monitor the security personnel's } \\
\text { performance regularly (qualifications, the actual performance of duty, etc.) }\end{array}$ & 3.53 & Highly Practiced \\
\hline 2. & $\begin{array}{l}\text { The manager oversees the performance of the security personnel through their } \\
\text { immediate superiors. }\end{array}$ & 3.50 & Highly Practiced \\
\hline 3. & $\begin{array}{l}\text { The management monitors the security personnel performance in terms of } \\
\text { his/her relationship with peers and client customers. }\end{array}$ & 3.48 & Highly Practiced \\
\hline 4. & $\begin{array}{l}\text { The management implements a policy to avoid over familiarization of security } \\
\text { personnel to the Clients. }\end{array}$ & 3.44 & Highly Practiced \\
\hline 5. & $\begin{array}{l}\text { The management conducts an evaluation of the security personnel his/her } \\
\text { effectiveness to the post. }\end{array}$ & 3.42 & Highly Practiced \\
\hline 6. & $\begin{array}{l}\text { The management recommends introduction or abolition of policies to the client } \\
\text { as applicable based on the observations of its security personnel. }\end{array}$ & 3.30 & Highly Practiced \\
\hline 7. & $\begin{array}{l}\text { The management provides initiatives in order to avoid leniency and carelessness } \\
\text { of its security personnel. }\end{array}$ & 3.44 & Highly Practiced \\
\hline & Aggregate Mean & 3.44 & Highly Practiced \\
\hline
\end{tabular}

Based on the aggregate mean of 3.44 , it indicates that the management implemented a policy to avoid over familiarization of security personnel to the clients and rated as highly practiced. As shown in the table IV, it reveals that the management coordinates with the client to monitor the security personnel's performance regularly (qualifications, the actual performance of duty, etc.) in most instances. The weighted mean of 3.53 denotes a highly practiced area. This specifies that security management communicates to the client regarding the performance of the security personnel and check their satisfaction on the guard's performance. The management gets feedback from the superiors and detachment commanders regarding the performance of the security personnel in the performance of their tour of duty and relationships with peers and client customers.

On the other hand, in the aspect where the management recommends introduction or abolition of policies to the client as applicable based on the observations of its security personnel, this is with the lowest mean of 3.30. This indicates that this was highly practiced but not as much as the other indicators. This indicates that there is opportunity to get better in commitment between the security agency and the client in aligning their policies that will serve as a guide in monitoring and evaluation the performance of the assigned security personnel in fulfilling the goals of the client, creates uniformity, ensures safety, provides accountability, improves job security, reinforces company's credibility and makes the workplace enjoyable and comfortable to work. Monitoring the workplace ensures that such policies are followed strictly and every employee is making sure that they are safe and care for everyone around them as well.

Performance monitoring and evaluation is a process that helps improve performance and achieve results. Employee performance evaluations and monitoring are beneficial to the productivity of an organization. It provides with the tools to gather information and communicate company and individual goals to all employees. It likewise gives a structure to a compensation for-execution framework that rewards representatives for effectively accomplishing those objectives. These assessments are instruments that can make representatives increasingly gainful and occupied with their occupations and in this manner make the organization progressively fruitful (Greiling, 2005).

Table $\mathrm{V}$ presents the results on the performance management practices as to developmental intervention.

Table V Perceived Performance Management Practices as To DeVelopment Intervention

\begin{tabular}{|c|l|c|c|}
\hline & \multicolumn{1}{|c|}{ Indicators } & Mean & \multicolumn{1}{|c|}{ Interpretation } \\
\hline 1. & $\begin{array}{l}\text { The management gives a thorough and complete orientation to security personnel before deployment } \\
\text { in order to equip them with the necessary information to successfully carry out their duties. }\end{array}$ & 3.59 & Highly Practiced \\
\hline 2. & $\begin{array}{l}\text { The management authorizes the security personnel's immediate superior to give out proper and } \\
\text { constructive feedback. }\end{array}$ & 3.43 & Highly Practiced \\
\hline 3. & $\begin{array}{l}\text { The management coordinates with the detachment with the necessary training and seminars that fit } \\
\text { the Clients need (Customer Service Seminar, Disaster Preparedness, Marksmanship Training, etc. })\end{array}$ & 3.64 & Highly Practiced \\
\hline 4. & The management implements human resource intervention like counseling, admin hearing, etc. & 3.34 & Highly Practiced \\
\hline 5. & $\begin{array}{l}\text { The management takes the necessary steps to discipline or control its security personnel as } \\
\text { recommended by the detachment commanders. }\end{array}$ & 3.48 & Highly Practiced \\
\hline 6. & $\begin{array}{l}\text { The management provides re-orientation, debriefing, and reassignment of its security personnel as } \\
\text { necessary. }\end{array}$ & 3.47 & Highly Practiced \\
\hline 7. & The management gives a recommendation to the client for the disposition of its security personnel. & 3.27 & Highly Practiced \\
\hline & Aggregate Mean & 3.46 & Highly Practiced \\
\hline
\end{tabular}


The aggregate mean of 3.46 indicates that the management coordinates with the detachment commanders as to the necessary training and seminars that fit the client needs and was highly practiced.

As presented in the table $\mathrm{V}$, it revealed that the practices on the coordination of the management with the detachment with the necessary training and seminars that fit the clients' need (Customer Service Seminar, Disaster Preparedness, Marksmanship Training, etc.) were considered as highly practiced based on the weighted mean of 3.64. This implies that the management conducts proper training and seminars to fit the clients' needs. The objective of training and seminar is to refresh the security guards knowledge and experience in developing basic skills and knowledge gained previously or gained while in the exercise of his/her duty as a matter of experience, to enhance current in-service and future individual and joint exercise of the profession. Proper training, without a doubt, improves a security officer's credentials and credibility as a professional. The training aims at employees performing at a level in alignment with the goals and objectives of the organization and its security operation. All employees, including security officers, must work towards a joint mission. Specifically, adequately trained personnel are crucial for several reasons.

The weighted mean of 3.27 indicates that in the aspect that the management gives a recommendation to the client for disposition of its security personnel. This got the lowest mean of 3.27 though highly practiced. This specifies that there is a room for improvement in terms of development intervention in giving a recommendation to the client for the disposition of its security personnel.

As per Swart et al., (2005), they are crossing over the execution hole alludes to actualizing an important preparing mediation for creating specific aptitudes and capacities of the representatives and upgrading worker execution. He further explained the idea by expressing that preparation encourages association to perceive that its labourers are not performing admirably in this manner; the establishment needs should shape their insight, aptitudes, and frames of mind. It is dependable, with the goal that representatives have a specific measure of learning identified with various employments. In any case, note this is not sufficient, and workers need to adjust to new prerequisites of employment execution continually. As such, associations need ceaseless arrangements for preparing and holding of workers and in this way not to hang tight for events of ability and execution holes.

Artley and Stroh (2001) highlighted on the role of learning and development in performance management practices that employee development is the main route to an improved organizational performance, which in turn need an understanding of the techniques and processes of the organizational, team and individual learning. Performance development reviews may be regarded as learning events, during which employees and teams can be encouraged to think about how and in which ways they want to develop themselves. This can lead to the establishment of a personal development plan outlining the actions they suggest to take to meet their development needs.

Chiaburu and Tekleab (2005) added that training is designed to enhance employees' job performance in an organization and helps employees to improve their ability. Mullins (2005) claimed that training might reduce frustration or anxiety of employees who are not familiar with skills for their jobs. After training, employees learn more and may improve their confidence and performance. Consequently, Harrison (2000) also made a similar conclusion that training contributes to the positive performance of an organization plan outlining the actions they suggest to take to meet their development needs.

Table VI presents the summarized data on perceived performance management practices. All the aspects of performance management were assessed as highly practiced as indicated by the overall aggregate mean of 3.43 .

Table Vi Summarized Data On The Perceived Performance MANAGEMENT PRACTICES

\begin{tabular}{|c|l|c|c|}
\hline & \multicolumn{1}{|c|}{ Indicators } & $\begin{array}{c}\text { Aggregate } \\
\text { Mean }\end{array}$ & Interpretation \\
\hline A. & Commitment and Target Setting & 3.45 & Highly Practiced \\
\hline B. & Performance Appraisal & 3.38 & Highly Practiced \\
\hline C. & Monitoring and Evaluation & 3.44 & Highly Practiced \\
\hline D. & Development Intervention & 3.46 & Highly Practiced \\
\hline & Overall Aggregate Mean & 3.43 & Highly Practiced \\
\hline
\end{tabular}

It very well may be seen from the information that among the arrangements, improvement mediation was exceptionally polished because the administration recognizes, organizes and gives formative chances to security faculty. At the point when a worker sees his objectives characterized, his execution challenges recognized and profession improvement arrangements set up to help advance his vocation, the impact is to spur the representative to accomplish those objectives. Making a complete arrangement for representative improvement and giving a worker accomplishment to take a stab freely motivate a more elevated amount of productivity. Commitment and target setting were highly practiced because the management has defined targets for each security personnel to meet the standard of the security agency and client goals. Furthermore, the management sets guidelines and approaches to align with the security agency's mission and vision properly. This could be done through monitoring and evaluation to ensure that the management coordinates with the client to monitor the security personnel's performance regularly (qualifications, the actual performance of duty, etc.). Although performance appraisal obtained the lowest mean, still highly practiced. This implies that motivated security personnel often lead to good performance. Thus performance appraisal has a significant impact in improving employees' productivity. 
C. Results of the Test of Significant Relationship: Table VII reveals the test of a significant relationship between the profile of the respondents and their assessment on the performance management practices in the security agency.

Table Vit Test Of Significant Relationship Between Profile of the Respondents and the Performance Management Practices

\begin{tabular}{|c|c|c|c|c|c|}
\hline Variable & Computed Chi-Square & df & Critical Value & Significance & Result \\
\hline \multicolumn{6}{|c|}{ A. Age } \\
\hline Commitment \& Target Setting & 5.101 & 3 & 7.815 & Not Significant & Accept Ho \\
\hline Performance Appraisal & 5.865 & 6 & 12.592 & Not Significant & Accept Ho \\
\hline Monitoring and Evaluation & 2.299 & 6 & 12.592 & Not Significant & Accept Ho \\
\hline Development Intervention & 2.088 & 3 & 7.815 & Not Significant & Accept Ho \\
\hline \multicolumn{6}{|c|}{ B. Gender } \\
\hline Commitment \& Target Setting & 0.014 & 2 & 5.991 & Not Significant & Accept Ho \\
\hline Performance Appraisal & 0.474 & 2 & 5.991 & Not Significant & Accept Ho \\
\hline Monitoring and Evaluation & 0.695 & 2 & 5.991 & Not Significant & Accept Ho \\
\hline Development Intervention & 1.687 & 1 & 3.841 & Not Significant & Accept Ho \\
\hline \multicolumn{6}{|c|}{ C. Civil Status } \\
\hline Commitment and Target Setting & 0.744 & 2 & 5.991 & Not Significant & Accept Ho \\
\hline Performance Appraisal & 1.926 & 4 & 9.488 & Not Significant & Accept Ho \\
\hline Monitoring and Evaluation & 0.976 & 4 & 9.488 & Not Significant & Accept Ho \\
\hline Development Intervention & 0.725 & 2 & 5.991 & Not Significant & Accept Ho \\
\hline \multicolumn{6}{|c|}{ D. Educational Attainment } \\
\hline Commitment \& Target Setting & 2.401 & 2 & 5.991 & Not Significant & Accept Ho \\
\hline Performance Appraisal & 0.892 & 4 & 9.488 & Not Significant & Accept Ho \\
\hline Monitoring and Evaluation & 2.603 & 4 & 9.488 & Not Significant & Accept Ho \\
\hline Development Intervention & 0.181 & 2 & 5.991 & Not Significant & Accept Ho \\
\hline \multicolumn{6}{|c|}{ E. Length of Service } \\
\hline Commitment \& Target Setting & 3.441 & 8 & 15.507 & Not Significant & Accept Ho \\
\hline Performance Appraisal & 14.003 & 16 & 26.296 & Not Significant & Accept Ho \\
\hline Monitoring and Evaluation & 13.560 & 16 & 26.296 & Not Significant & Accept Ho \\
\hline Development Intervention & 11.406 & 8 & 15.507 & Not Significant & Accept Ho \\
\hline
\end{tabular}

It can be seen from the table that there is no significant relationship between the profile of the respondents and the performance management practices. This implies that the level of best practices and administration of performance management practices is highly practiced as managers continuously conduct monitoring on their plans and actions in order to maintain effectiveness and efficiency in carrying out the functions of the management. The performance management practices made by the security agents have a positive impact on employee commitment, performance appraisal, monitoring and evaluation, and development intervention. This is because it covers all the parameters required and its objective gives a clear idea of what the client expects.

\section{CONCLUSION}

The level of best practices and administration of performance management practices is highly practiced as managers continuously conduct monitoring on their plans and actions in order to maintain effectiveness and efficiency in carrying out the functions of the management. The performance management practices made by the security agents have a positive impact on employee commitment, performance appraisal, monitoring and evaluation, and development intervention. This is because it covers all the parameters required and its objective gives a clear idea of what the client expects.

\section{REFERENCES}

[1] Baker, B. (2010). Grasping the nettle of non-state policing. Journal of International Peacekeeping, 14(3-4), 276-300. Retrieved from http://bit.ly/2UNDI90

[2] Brockner, J. (2002). Making sense of procedural fairness: How high procedural fairness can reduce or heighten the influence of outcome favorability. Academy of management review, 27(1), 58-76. Retrieved from http://bit.ly/2I9lzg7

[3] Burton, K. (2012). A study of motivation: How to get your employees moving. Retrieved from https://goo.gl/FkTVeS.

[4] Chiaburu, D.S. \& Tekleab, A.G. (2005). Individual and contextual influences on multiple Dimensions of training effectiveness. Journal 
of European Industrial Training, 29(8), 604-26. Retrieved from http://bit.ly/2D5chNT

[5] Chintalloo, S \& Mahadeo, J. (2013). Effect of motivation on employees' work performance at Ireland Blyth Limited: Proceedings of 8th Annual London Business Research Conference Imperial College, London, UK, 8, Retrieved from http://bit.ly/2UJnNIY

[6] Day, D. V. (2000). Leadership development: A review in context. The leadership quarterly, 11(4), 581-613. Retrieved from http://bit.ly/ $2 \mathrm{ImCY} 4 \mathrm{~g}$

[7] Eraut, M. (2004). Informal learning in the workplace. Studies in continuing education, 26(2), 247-273. Retrieved from http://bit.ly/ 2G1sIeS

[8] Graphite, M. (2001). Performance management system. Retrieved from https://goo.gl/T2Rxg8

[9] Greiling, D. 2005. Performance measurement in the public sector: The German experience. International Journal of Productivity and Performance Management, 54(7), 551-567. Retrieved from http:// bit.ly/2YZnpFB

[10] Harrison, R. (2000). Employee development. Beekman Publishing, Silver Lakes Pretoria.

[11] Kandula, S. R. (2006). Performance management. In performance management Strategy intervention drivers (1st Ed.). Retrieved from http://bit.ly/2WZXtb3

[12] Kristof-Brown, A. L. \& Stevens, C. K. (2001). Goal congruence in project teams: Does the fit between members' personal mastery and performance goals matter? Journal of Applied Psychology, 86(6), 1083-1095. Retrieved from http://bit.ly/2Z9hcae

[13] Lawler, E. E. (2003). Reward Practices and performance management system effectiveness. Center for Effective Organizations. Retrieved from https://goo.gl/7KwU6E.

[14] Lindblad, M. (2007). The impact of work-related goals on employee commitment. Retrieved from http://bit.do/ekKAu.
[15] Locke, E. A. \& Latham, G. P. (2002). Building a practically useful theory of goal setting and task motivation. American Psychologist, 57(9), 705-717. Retrieved from http://bit.ly/2VEdu6p

[16] Johnson, E. K. (2000). The practice of human resource management in New Zealand: strategic and best practice? Asia Pacific Journal of Human Resources, 38(2), 69-83. Retrieved from http://bit.ly/ 2UrpuLF

[17] Meyer, J. P. \& Herscovitch, L. (2001). Commitment in the workplace: Toward a general model. Human Resource Management Review, 40(4), 383-395. Retrieved from http://bit.ly/2UpGPF5

[18] Muchinsky, P. M. (2000). Emotions in the workplace: The neglect of organizational behaviour. Journal of Organizational Behaviour. 21(7), 801-805. Retrieved from http://bit.ly/2U2Qv3a

[19] Mullins, J.L. (2005). Management and organizational behaviour. (7th Ed.). Pearson Education Limited.

[20] Peckley, M. \& Fontanos, T. (2012). Security forces and guards manual (In relation to RA.5487 as Amended) with special topic on school security management. Quezon City: Wiseman's Book Trading Inc

[21] Robbins, S.P. \& Coulter, M. (2002). Management. (7th Ed.). Upper Saddle River, NJ: Prentice Hall.

[22] Robbins, S. (2003). The role of motivation and self-regulatory behaviours on first-year college adjustment. Unpublished Manuscript, Iowa City, IA: ACT.

[23] Rue, L., Byars, L. \& Ibrahim, N. (2013). Management skills and application. ( $6^{\text {th }}$ Ed.). New Jersey: Prentice-Hall International.

[24] Štangl Šušnjar, G. \& Zimanji, V. (2005). Menadžment ljudskih resursa (Human Resource Management). Subotica: Ekonomski fakultet.

[25] Swart, J., Mann, C., Brown, S. \& Price, A. (2005). Human resource development: Strategy and tactics. Oxford. Elsevier ButterworthHeinemann Publications. Retrieved from http://bit.ly/2D3H5ic 